\title{
ORGANIZATIONAL AND INDIVIDUAL'S FACTORS AS A PREDICTORS OF INNOVATIVE WORK BEHAVIOUR AMONG SOFTWARE ENGINEERS
}

\author{
Saima Arzeen \\ Lecturer, \\ Department of Psychology, University of Peshawar, \\ KPK, Pakistan \\ Email: saimaarzeenmehar@uop.edu.pk

\section{Muhammad Jahanzeb Khan} \\ Professor, \\ Department of Psychology, University of Peshawar, \\ KPK, Pakistan \\ Email: yosafzai@yahoo.com

\section{Naeema Arzeen} \\ Lecturer, \\ Department of Psychology, NUMAL University, \\ Islamabad, Pakistan. \\ Email: narzeen@numl.edu.pk
}

\begin{abstract}
This survey research design study was conducted to explore the organizational (TRF $\& I C)$ and individual's factors (PE, OBSE \& RIL) as a predictor of innovative work behaviour among Information Technology Experts. A sample of $(N=300)$ software engineers with the age range of 25-45 were selected from various Government Sector Departments. For data collection, MLQ (Bass \& Avolio, 1997) CIS (Scott \& Bruce, 1994), PES (Spreitzer, 1995b), OBSE (Pierce, Gardner, Cummings \& Dunham, 1989), RIS (Walumbwa \& Hartnell, 2011) and IWBS (Janssen, 2000), were used. Appropriate statistical analysis (Correlational \& multiple regression) were used to assess the psychometric soundness of instrument and hypotheses testing respectively. Results confirmed that the desired pattern of relationship among the variables. However, results also confirmed that control variables (age, work experience and educational level) were not a good predictors of the innovative work behaviour. Furthermore, the findings of the study highlighted that all the organizational and individual's factors significantly predict the IWB. Future implications \& suggestions for study have also been discussed.
\end{abstract}




\section{KEYWORDS}

Innovative work behavior, Psychological empowerment, Leadership styles

\section{INTRODUCTION}

In the $21^{\text {st }}$ century, organizations long term survival depends upon their ability to bend according to the demands of the business environment i.e., to stay innovative (Baer, 2012). Therefore, employees' innovative work behaviour gained a lot of attention in studies conducted in the field of organizational behaviour e.g., innovative performance \& capability (Aslam, Aslam \& Ismail, 2017), organizational effectiveness (Tahsildari, Hashim \& Wan, 2014), wellbeing (Abbas, khalily\& Riaz, 2016), workrelated attitudes and work engagement (Park, Tseng \& Kim, 2016; Sameer \&Ohly, 2017). These studies highlighted the need for exploring the antecedents of IWB at the individual and organizational levels. Therefore, the present study emphasis predicting the role of individual's factors (PE, OBSE \&RIL) \& organizational factors (TFL \& IC) in the development of IWB among software engineers. The rationale for choosing software engineers was their crucial role as the backbone of every business organization. Text In literature, the term Innovative Wok Behaviour (IWB) is viewed as the individual capacity to generate, introduce, promote and implement a new idea at the workplace. So, an individual's innovative work behaviour process involves at least three stages or phases namely idea generation (presentation or finding a unique solution to the problem), idea promotion (getting human and technical support through explaining the vision) and idea realization/implementation (involves the bringing the idea into reality). (Janssen, 2000).

\section{Transformational Leadership style}

Leadership studies highlighted that the most effective and proficient leadership styles are transformational leadership style (TRF)because such leaders can direct, inspire and stimulate their subordinates in such a way that increases their confidence, satisfaction, wellbeing, creativity, performance, OCB and commitment (Datche, 2015; Haghighi, \& Maleki, 2016; Hatter \& Bass, 1988; Piccolo \& Colquitt, 2006; Sharifirad, 2013; Zhou, \& Pan, 2015). Empirical evidence suggested that leaders with transformational style have a significant positive impact on employees IWB (Abbas \& Riaz, 2012; Ahmed, 2016; Contreras, Espinosa, Dornberger \& Acosta, 2017).

\section{Innovative Climate (IC)}

The term innovative climate is defined as the perception of workers about the working environment that promotes creative and innovative performance (Scott\& Bruce, 1994). Researchers claimed that such a work environment build when the organization and staff (leaders \& members) synchronize in such a way that can stimulate and guide each other to their work independently (Torokoff;2015). Moreover, previous studies also highlighted that the innovative climate of an organization strongly predicts the 
employees’ IWB (Grau, Vallejo, \& Tomás, 2004).

\section{Psychological Empowerment (PE)}

According to spritzer (1995), psychological empowerment is an intrinsic task motivation construct. Psychologically empowered individuals showed a high level of commitment, sense of confidence, independence \& control over choices in initiating and regulating the administrative and strategic outcomes at the workplace (Thomas $\&$ Velthouse, 1990). Empirical pieces of evidence also suggested that such individuals do their work in a more innovative way than individuals' who failed to attain this sense of empowerment (Kristof-Brown, Zimmerman, \& Johnson, 2005; Redmond, Mumford, \&Teach, 1993; Seibert, Wang, \& Courtright, 2011; Spreitzer, 1995b; Spreitzer, 2008).

\section{Organizational Based self-esteem (OBSE)}

OBSE indicate the individual's views about his or her worth at the workplace (Pierce, Gardner, Cummings, \& Dunham, 1989). Researchers pointed out that employees' OBSE influence their job-related attitudes which in turn enable them to involve innovative activities to adjust to organizational change (Ariani, 2012; Rotich, 2016; Staehle-Moody, 1998; Uçar, \& Ötken 2013).

\section{Relational Identification with Leader (RIL)}

According to Sluss \& Asforth(2007) defined the term relational identification is a sense of belongingness in a given role relationship at the workplace. Studies suggested that employees' sense of oneness with leaders bring changes in their behaviour at work setting (Walumbwa and Hartnell, 2011; Wang \& Howell, 2012). For example, a study conducted by Liqun, Mingjian, Qiang, (2017) confirmed that RIL strongly predicts the creative behaviour of workers.

\section{Conceptual Frame Work of the Study}

i. Psychological Empowerment (PE)

ii. Organizational based Self-esteem (OBSE)

iii. Relational identification with leaders (RIWL) $\longrightarrow \begin{aligned} & \text { Innovative work } \\ & \text { Behavior (IWB) }\end{aligned}$

iv. Transformational leadership style (TRF)

v. Innovative climate (IC)

\section{RESEARCH OBJECTIVES}

1. To investigate the psychometric properties of instruments used in the study.

2. To explore the predicting role organizational factors (TRF \& IC)

3. To explore the predicting role of individual's factors (PE, OBSE, RIWL) in IWB. 


\section{RESEARCH QUESTION}

1. Does organizational and individual's factors predict the innovative work behavior of software engineers?

\section{RESEARCH HYPOTHESES}

1. Text Transformational leadership style and its sub-dimensions will positively predict the IWB of software engineers.

2. Innovative climate will positively predict the IWB of software engineers.

3. Psychological empowerment and it's all dimensions will positively predict the IWB of software engineers.

4. Organization based self-esteem will positively predict the IWB of software engineers.

5. Relational identification with leader will positively predict the IWB of software engineers.

\section{RESEARCH METHODOLOGY}

For the current study a sample of 300 software engineers was selected through purposive sampling from various Government institutes located in twin cities (Rawalpindi and Islamabad)) of Pakistan. The participant age ranged was from 25-45 $(\mathrm{M}=32.39, \mathrm{SD}=7.32$ ) years. For the current study, some controlled variables i.e., age, job tenure and educational level; (Hu \& Liden, 2011; Ng \& Feldman, 2013).

For the present study, several variables were used as independent variables: Individuals factors (PE, OBSE \& RIL) and organizational factors (TRF \& IC). For measuring these variables following instruments were used: PES (Spreitzer, 1995b); OBSE (Pierce, Gardner, Cummings and Dunham, 1989); RIS (Walumbwa \& Hartnell, 2011); Multifactor Leadership Questionnaire (Bass and Avolio, 1997) and climate for innovation (Scott and Bruce; 1994). Empirical studies suggested that all measures were highly valid and reliable. (Avolio, Bass, \& Jung, 1999; Siegall \& Gardner, 2000; Van Dyne et al., 2000). Furthermore, IWB was taken as DV and the measure used for it was 5- point Likert scale consisted of 9 items and having Cronbach alpha 89 (Janssen; 2000).

Before the data collection, the researcher approached the higher authority of Government institutes for taking permission from them. On the day of data collection, only those participants were contacted who were involved in software development and hold BS (Hons) in software engineering. At the start, a researcher told them about the purpose of the study and took their consent for participation in the study. After building rapport, the researcher gave them a set of questionnaires to fill in. During this time, the researcher continuously tried to encourage or facilitate them for giving honest responses. In the end, participants were thanked for their cooperation and time. 


\section{DATA ANALYSIS AND RESULTS}

For the current study, SPSS 22 was sued to analyze that data. The appropriate statistical analysis of the study is Descriptive, Cronbach's Alpha, Correlational and Multiple regression analyses.

Table 1: $\quad$ Frequency and Percentage distribution of Demographic features of sample for study $(N=300)$

\begin{tabular}{|c|c|c|c|}
\hline Variables & Classes & $F$ & $\%$ \\
\hline \multirow[t]{4}{*}{ Age } & $25-30$ & 90 & 30 \\
\hline & $31-35$ & 75 & 25 \\
\hline & $36-40$ & 85 & 28.3 \\
\hline & $41-45$ & 50 & 16.6 \\
\hline \multirow[t]{3}{*}{ Education level } & Bs (Hons) & 110 & 36.6 \\
\hline & Master & 100 & 33.3 \\
\hline & Ms & 90 & 30 \\
\hline \multirow[t]{4}{*}{ Work Experience } & 6months-1 year & 95 & 31.6 \\
\hline & $2-5$ year & 105 & 35 \\
\hline & 6-10 year & 85 & 28 \\
\hline & 16 and above & 15 & 5 \\
\hline \multirow[t]{2}{*}{ City } & Rawalpindi & 170 & 56.6 \\
\hline & Islamabad & 130 & 43.3 \\
\hline \multirow[t]{2}{*}{ Departments/offices } & $\begin{array}{l}\text { Govt office/ administration } \\
\text { section and IT directorate }\end{array}$ & 185 & 61.6 \\
\hline & Universities & 115 & 38.3 \\
\hline
\end{tabular}

Table1 indicates the distribution of demographic variables terms of frequency and percentages.

Table 2: Psychometric Properties for Scales of the Present Study $(N=300)$

\begin{tabular}{|c|c|c|c|c|c|c|c|}
\hline Variable & $M$ & $S D$ & Items & $\alpha$ & Potential & Actual & Skew \\
\hline TRF & 83.33 & 14.00 & 20 & .88 & $1-5$ & $3.29-3.89$ & -.32 \\
\hline $\begin{array}{l}\text { Idealized influence } \\
\text { (attributes) }\end{array}$ & 14.24 & 3.42 & 4 & .80 & $1-5$ & $3.36-3.90$ & -.33 \\
\hline $\begin{array}{l}\text { Idealized influence } \\
\text { (behaviours) }\end{array}$ & 14.60 & 3.33 & 4 & .72 & $1-5$ & $3.74-3.96$ & -.42 \\
\hline
\end{tabular}


PJER, Vol 4, Issue 4 (2021)

Organizational and individual's...

\begin{tabular}{lccccccc}
\hline $\begin{array}{l}\text { Inspirational } \\
\text { motivation }\end{array}$ & 15.48 & 3.06 & 4 & .84 & $1-5$ & $3.77-4.10$ & -.54 \\
$\begin{array}{l}\text { Intellectual } \\
\text { stimulation }\end{array}$ & 14.80 & 2.92 & 4 & .75 & $1-5$ & $3.69-4.0$ & -.37 \\
$\begin{array}{l}\text { Individualized } \\
\text { consideration }\end{array}$ & 14.20 & 3.57 & 4 & .76 & $1-5$ & $3.50-4.26$ & -.83 \\
IWB & 44.42 & 5.57 & 9 & .88 & $1-5$ & $3.64-3.96$ & -.55 \\
PE Scale & 48.8 & 10.56 & 12 & .81 & $1-5$ & $3.55-4.36$ & -.26 \\
RIS scale & 53.08 & 9.54 & 10 & .89 & $1-7$ & $4.49-5.82$ & -.91 \\
OBSE scale & 55.70 & 10.51 & 10 & .88 & $1-7$ & $4.95-5.81$ & -.77 \\
CIS & 68.90 & 8.09 & 22 & .69 & $1-5$ & $2.38-3.92$ & -.57 \\
\hline
\end{tabular}

Table 2 show that all instruments of the study were internally reliable and suitable for the current study.

Table 3: $\quad$ Inter-Scale Correlations of the Variables Study $(N=300)$

\begin{tabular}{|c|c|c|c|c|c|c|c|c|c|c|c|c|c|c|c|}
\hline $\begin{array}{c}\text { Va } \\
\mathbf{r}\end{array}$ & 1 & 2 & 3 & 4 & 5 & 6 & 7 & 8 & 9 & 10 & 11 & 12 & 13 & 14 & 15 \\
\hline 1 & -- & $81^{*}$ & $.79 *$ & $.78^{*}$ & $.84 *$ & $.68 *$ & $.40 *$ & $\begin{array}{r}.36 * \\
*\end{array}$ & $\begin{array}{r}.31 \\
*\end{array}$ & $.21 *$ & $\begin{array}{r}.35^{*} \\
*\end{array}$ & $.22^{*}$ & $.40^{*}$ & $\begin{array}{r}.11^{*} \\
*\end{array}$ & $.30^{*}$ \\
\hline 2 & -- & -- & $.65^{*}$ & $.48^{*}$ & $.51 *$ & $.43^{*}$ & $.49 *$ & $\begin{array}{r}.43 * \\
*\end{array}$ & .06 & $.21 *$ & $\begin{array}{r}.40 * \\
*\end{array}$ & $.37 *$ & $.50 *$ & $\begin{array}{r}.18 * \\
*\end{array}$ & $.30^{*}$ \\
\hline 3 & -- & -- & -- & $.55^{*}$ & $.58 *$ & $.31 *$ & $.41 *$ & $\begin{array}{r}.30 * \\
*\end{array}$ & $\begin{array}{r}.23 \\
*\end{array}$ & $.18^{*}$ & $\begin{array}{r}.29 * \\
*\end{array}$ & $.23 *$ & $.32 *$ & .19 & $.26^{*}$ \\
\hline 4 & -- & -- & -- & -- & $.65^{*}$ & $.39 *$ & $.40 *$ & $\begin{array}{r}.62 * \\
*\end{array}$ & $\begin{array}{r}.35 \\
*\end{array}$ & $.31^{*}$ & $\begin{array}{r}.39 * \\
*\end{array}$ & $.44^{*}$ & $.64^{*}$ & .08 & $.29 *$ \\
\hline 5 & -- & -- & -- & -- & -- & $.43^{*}$ & $.35^{*}$ & $\begin{array}{r}.65 * \\
*\end{array}$ & .09 & $.26^{*}$ & $\begin{array}{r}.36 * \\
*\end{array}$ & $.56^{*}$ & $.24 *$ & $\begin{array}{r}.11 * \\
*\end{array}$ & $.18^{*}$ \\
\hline 6 & -- & -- & -- & -- & -- & -- & $.14^{*}$ & $\begin{array}{r}.35 * \\
*\end{array}$ & $\begin{array}{r}.40 \\
*\end{array}$ & .18 & $\begin{array}{r}.29 * \\
*\end{array}$ & $.20 *$ & $.43^{*}$ & .02 & $.10^{*}$ \\
\hline 7 & -- & -- & -- & -- & -- & -- & -- & $\begin{array}{r}.65 * \\
*\end{array}$ & $\begin{array}{r}.42 \\
*\end{array}$ & $.38^{*}$ & $\begin{array}{r}.46^{*} \\
*\end{array}$ & $.69 *$ & $.58 *$ & $\begin{array}{r}.21 * \\
*\end{array}$ & $.60 *$ \\
\hline 8 & -- & -- & -- & -- & -- & -- & -- & -- & $\begin{array}{r}79 \\
*\end{array}$ & $.78^{*}$ & $\begin{array}{r}.84 * \\
*\end{array}$ & $.69 *$ & $.57 *$ & .13 & $.26^{*}$ \\
\hline 9 & -- & -- & -- & -- & -- & -- & -- & -- & -- & $.57^{*}$ & $\begin{array}{r}.56^{*} \\
*\end{array}$ & .09 & .07 & .16 & $.24^{*}$ \\
\hline 10 & -- & -- & -- & -- & -- & -- & -- & -- & -- & -- & $\begin{array}{r}.69 * \\
*\end{array}$ & $.27^{*}$ & $.34 *$ & .13 & $.25^{*}$ \\
\hline 11 & & & & & & & & & & & & $.44^{*}$ & $.42 *$ & .34 & $.22 *$ \\
\hline 12 & & & & & & & & & & & & & $.52 *$ & .40 & $.28^{*}$ \\
\hline
\end{tabular}




\begin{tabular}{l}
\hline 13 \\
14 \\
15
\end{tabular}

Table 3 presented the inter scales correlation between the variables of the study. Results showed that all variables significantly positively linked with IWB.

Table 4: Multiple Regression Analysis of the predicting varaiables on IWB $(N=$ 300)

\begin{tabular}{|c|c|c|c|}
\hline & & IWB & \\
\hline \multirow[t]{2}{*}{ Block I } & Predictors & $\Delta R^{2}$ & $B$ \\
\hline & $\begin{array}{l}\text { Control variables (age, } \\
\text { education and work } \\
\text { experience respectively) }\end{array}$ & .098 & $0.18,0.21,1.17$ \\
\hline Block II & TRF & .21 & $.46^{* * *}$ \\
\hline \multirow[t]{5}{*}{ Block III } & $\mathrm{PE}$ & .39 & $.31 * * *$ \\
\hline & OBSE & & $.15 * * *$ \\
\hline & RIWL & & $.17 * * *$ \\
\hline & IC & & $.51 * * *$ \\
\hline & Total $\mathrm{R}^{2}$ & .69 & \\
\hline
\end{tabular}

Table 4 revealed the all predicting variables impact on IWB. For this purpose multiple regression analysis was carried out. Above table findings indicates that inclusively variance in IWB is $69 \%$ at $\{F(8,391)=153.61, p<.001\}$. whereas, the change happens because of moderating variables $[\operatorname{PE}(\beta=.31, t=7.03, p<.001), \operatorname{OBSE}(\beta=.15, t=3.28$, $p<.001)$, RIWL $(\beta=.16, t=3.63, p<.001)$ and CIS $(\beta=.10, t=2.68, p<.001)$. Hence, all the predicting variables were found have significant effect on IWB.

Table 5: $\quad$ Multiple Regression Analysis of Transformational Leadership style sub-constructs in Predicting IWB $(N=300)$

\begin{tabular}{lcc}
\hline Models & \multicolumn{2}{c}{ Innovative Work Behavior } \\
\hline Predictor Variable & $B$ & $\Delta R^{2}$ \\
\hline IA & $.17^{*}$ & .33 \\
IB & $.33^{* * *}$ & \\
\hline
\end{tabular}




\begin{tabular}{ll}
\hline IM & $.18^{*}$ \\
IS & $.39 * *$ \\
IC & $.15^{*}$ \\
\hline$* p<.05$ &
\end{tabular}

Table 5 explained the findings of multiple regression analysis of Independent variable (TRF) and it sub dimensions in Predicting outcome (IWB). Overall tables findings indicates the $33 \%$ of the variance in IWB is labeled to TRF constructs $\left(\mathrm{R}^{2}\right.$ $=.33)$. Overall the model is proved significant $\{\mathrm{F}(5,395)=39.66, \mathrm{p}<.001\}$ and its dimensions.

Table 6: $\quad$ Multiple Regression Analysis of Psychological empowerment subconstructs in Predicting IWB $(N=300)$

\begin{tabular}{ccc}
\multicolumn{1}{l}{ Models } & Iwb & \\
\hline Predictor Variable & $B$ & \\
\hline PE (M) & $.16^{*}$ & \\
PE (C) & $.29^{* * *}$ & \\
PE (SD) & $.25^{* * *}$ & .44 \\
PE(IM) & $.13^{* * *}$ & \\
\hline
\end{tabular}

$* p<.05, * * p<.01, * * * p<.001$

Table 6 proved that psychological empowerment and its dimensions are significant predictors of IWB. The overall model suggested the $44 \%$ of change on the part of PE $\{F(5,395)=39.66, p<.001\}$ PE $(\beta=.31, t=7.03, p<.001)$ and its dimensions in predicting IWB.

\section{CONCLUSIONS}

In today business world, organizational survival depends on its ability to stay competitive and innovative. Therefore, the topic of innovation and innovative work behaviour always remains a center of attention. This present study aimed to expose those antecedents that predict the employees' innovative tendencies or behaviours at the workplace. In the light of previous findings, the current study provides an insight into the importance of some organizational and individual factors as predictors of IWB. The findings of the study suggested that all the hypotheses of the study were confirmed in desirable directions.

\section{DISCUSSION}

The current was conducted on the sample of 300 software engineers taken from the twins' cities of Pakistan i.e., Rawalpindi and Islamabad. The study aimed to identify the individual and organization factors as predictors of IWB among Software engineers. For this purpose, correlational and multiple regression analyses were carried 
out. To assess the sample, a frequency distribution table showing the frequency and percentages of the sample was made (see, Table-1). Similarly, table 2 show the psychometric properties of the study variables. Overall, values of means, SD, skewness kurtosis and alpha reliability showed that the sample was normally distributed and scales of all variables were internally consistent (ranged from .68 to .88) and suitable for the current study (see table 2).

Table 3 showed the interscales correlation analysis which revealed that all scales and their subscales are related with the outcome variable (IWB) in desirable directions i.e., positive. (see also. Burns,2003; Oke, Munshi, \& Walumbwa, 2009). Multiple regression analysis also highlighted that that all the individual factors ( PE, RIL \&OBSE)and organizational factors ( TRF \& IC)variables are good predictors of innovative work behaviour among software engineers (see table 4). The software engineers are highly professional and skilful persons. They need a highly stimulating and regulating environment (innovative climate) in which they can exhibit all traits of transformational leaders (visionary, inspirational, goal-oriented, highly motivated and charismatic) (see Ivancevich, Konopaske, \& Mattteson, 2008; Pilli, 2012; Shamir, House, \& Arthur, 1993). Therefore, they have a lot of capacity to take initiative and work independently (psychological empowered) (see Thomas \& Velthouse, 1990; Choi, Goh, Adam \& Tan, 2016; Lan a, Chong, 2015). As a result, they developed a sense of being worth in them which later on, encourage them to trust their abilities or skills rather than external factors (see, Howell \& Higgins, 1990; Pierce et al., 1993).In addition to this, research findings revealed that employees' sense of belongingness (with their leaders as a role model) also play a significant role in directing and guiding them to do work innovatively. (See also, Yukl, 2010).Additionally, Shin \& Zhou, (2003) stated that the leader as a mentor enhance this relationship of leader-followers in provoking the RIL.

\section{RECOMMENDATIONS}

In the light of current study findings, possible practical implications are as follow:

This study highlights the importance of personal or individual factors in making an organization competitive.

The role of leaders and their styles in facilitating employees for delivering their best. Impact of organizational role in developing of working environment that encourages both leaders and followers.

This study also directs the high authority to appoint those leaders who are psychologically empowered and are charismatic or inspirational. Moreover, they also try their recruit those employees who have a sense of being worth and psychological empowered too.

As the IT sector is the backbone of any organization, therefore, every organization should an effort to provide a plate form where experts/leaders of various fields can 
directly interact or work with employees. This will increase the worker identification with their leaders.

\section{REFERENCES}

Abbas, G., \& Riaz, M. N. (2012), Relationship between transformational leadership style and innovative work behavior in educational institutions, Journal of Behavioural Sciences, 22(3), 18-32.

Abbas, G., Khalily, M. T., \& Riaz, M. N. (2016), Mediating Role of Work-Related Attitudes between Leadership Styles and Well-Being. Pakistan Journal of Commerce \& Social Sciences, 10(2)

Ahamad (2016).The Effects of Transformational Leadership towards Teachers Innovative Behavior in Schools. International Journal of Scientific and Research Publications, Volume 6, Issue 5, ISSN 2250-3153 Retrieved December 23, 2017, from http://www.bing.com/cr?IG=BF832DD54E9E4C94A96773C223F103E4\&CID=103 C3F8144A76C1919EB34E045086D60\&rd=1\&h=Q9xkuyTWHfROzg3vfTQ036vJbiLlMoMO8DY19ckq0\&v=1\&r=http\%3a\%2f\%2fwww.ijsrp.org\%2fresearch-paper0516\%2fijsrp-p5345.pdf\&p=DevEx,5067.1

Ariani, D. W. (2012). The relationship between social capital, organizational citizenship behaviors, and individual performance: An empirical study from banking industry in Indonesia. Journal of Management Research, 4(2), 226-241.

Aslam, H., Aslam, B., \& Ismail, L., (2017). The Effect Of Employee's Innovative Work Behavior on Innovative Output. Global Journal of Research in Business \& Management, 6(2), 461-468.

Avolio, B. J., Bass, B. M., \& Jung, D. I (1999), Re-examining the components of transformational and transactional leadership using the Multifactor Leadership, Journal of Occupational and Organizational Psychology, 72(4), 441-462. doi:10.1348/096317999166789

Baer, M. (2012). Putting Creativity to Work: The Implementation of Creative Ideas in Organizations. Academy of Management Journal, 55(5), 1102-1119. doi: $10.5465 / \mathrm{amj} .2009 .0470$

Bass, B. M., \& Avolio, B. J. (1997). Full Range Leadership Development: Manual for Multifactor Leadership Questionnaire. California: Mind Garden.

Binnewies, C., Ohly, S., \& Niessen, C. (2008). Age and creativity at work. Journal of Managerial Psychology, 23(4), 438-457. doi:10.1108/02683940810869042

Burns, J. M. (2003). Transforming leadership: A new pursuit of happiness (Vol. 213). Grove Press.

Choi, S. L., Goh, C. F., Adam, M. B., \& Tan, O. K. (2016). Transformational leadership, empowerment, and job satisfaction: the mediating role of employee empowerment. Human Resources for Health, 14(1). doi:10.1186/s12960-016-0171-2

Contreras Torres, F. V., Dornberger, U., Espinosa, J. C., \& Cuero Acosta, Y. A. (2017, December). Organizational climate for innovation: A study in Vietnam. In Conference Proceedings iN4iN NETWORK CONFERENCE 2017 Entrepreneurship and 

Innovation for Competitiveness, ISBN: 3-934693-27-X (2017). Universität Leipzig.

Datche, E. A. (2015). Influence of transformational leadership on organizational performance of state corporations in Kenya (Doctoral dissertation, JKUAT).

Grau, J. B. I., Vallejo, R. D. D., \& Tomás, E. A. (2004). El burnout y las manifestaciones psicosomáticas como consecuentes del clima organizacional y de la motivación laboral [Burnout and psychosomatic manifestations as a consequence of the organizational climate and of work motivation]. Psicothema, 16, 125-131.

Hater, J.J. \& Bass, B.M. (1988). Superior's Evaluations and Subordinate's Perceptions of Transformational and Transactional Leadership. Journal of Applied Psychology, 73, 695-702.

Haghighi, F.B., \& Maleki, Z.V. (2016). The Relationship between Transformational Leadership Style and Behavior of Organizational Citizen (Case Study: Ghavamin Bank). International Journal of Learning and Development, 6, 80-91.

Howell, J. M., \& Higgins, C. A. (1990). Champions of technological innovation. Administrative science quarterly, 317-341.

Hu, J., \& Liden, R. C. (2011). Antecedents of team potency and team effectiveness: An examination of goal and process clarity and servant leadership. Journal of Applied psychology, 96(4), 851.

Ilmarinen, J. (2006). The ageing workforce-challenges for occupational health. Occupational Medicine, 56(6), 362-364.

Ivancevich, J. M., Konopaske, R., \& Matteson, M. T. (2008). Organizational Behavior and Management (8e ed.). Boston: McGraw-Hill Irwin.

Janssen, O. (2000). Job Demands, Perceptions of Effort-Reward Fairness and Innovative Work Behaviour. Journal of Occupational and Organizational Psychology, 73: pp287-302.

Jung, D. I., Chow, C., \& Wu, A. (2003). The role of transformational leadership in enhancing organizational innovation: Hypotheses and some preliminary findings. The Leadership Quarterly, 14(4-5), 525-544. doi:10.1016/s1048-9843(03)00050-x

Kristof-Brown, A. L., Zimmerman, R. D., \& Johnson, E. C. (2005). Consequences OF INDIVIDUALS'FIT at work: A meta-analysis OF person-job, person-organization, person-group, and person-supervisor fit. Personnel psychology, 58(2), 281-342.

Lan, X. M., \& Chong, W. Y. (2015). The mediating role of psychological empowerment between transformational leadership and employee work attitudes. Procedia-Social and Behavioral Sciences, 172, 184-191.

Liqun W,Mingjian Z, Qiang, (2017). "The influence of leader's creativity on employees' and team creativity: Role of identification with leader", Nankai Business Review International, Vol. 8 Issue: 1, pp.22-38, https://doi.org/10.1108/NBRI-05-2016-0020

Ng, T. W. H., \& Feldman, D. C. (2013). A meta-analysis of the relationships of age and tenure withinnovation-related behaviour. Journal of Occupational and Organizational Psychology, 86,

Oke, A., Munshi, N., \& Walumbwa, F. O. (2009). The influence of leadership on innovation processes and activities. Organizational Dynamics, 38(1), 64-72 DOI: $10.1016 /$ j.orgdyn.2008.10.005

Park, S., Tseng, Y., \& Kim, S. (2016). The Impact of Innovation on Job Satisfaction: Evidence from U.S. Federal Agencies. Asian Social Science, 12(1), 274. doi:10.5539/ass.v12n1p274 
Piccolo, R. F., \& Colquitt, J. A. (2006). Transformational leadership and job behaviors: the mediating role of core job characteristics. Academy of Management Journal, 49(2), 327-340. doi: 10.5465/AMJ.2006.20786079

Pierce, J. L., Gardner, D. G., Dunham, R. B., \& Cummings, L. L. (1993). Moderation by organization-based self-esteem of role condition-employee response relationships. Academy of Management Journal, 36(2), 271-288.

Pierce, JL., Gardner, DG., Dunham, RB. \& Cummings, LL. 1989. Organization-based selfesteem: Construct definition, measurement, and validation, The Academy of Management Journal, 32(3), 622-648

Pilli, S. N. (2012). Factors affecting employee innovative behavior in for-profit health care organizations (Doctoral dissertation).

Redmond, M. R., Mumford, M. D., \& Teach, R. (1993). Putting creativity to work: Effects of leader behavior on subordinate creativity. Organizational Behavior and Human Decision Processes, 55(1), 120-151. doi: DOI: 10.1006/obhd.1993.1027

Rotich,, R. K. (2016)The Impact of Organizational-Based Self Esteem on Work ... Retrieved August 29, 2017, from http://www.bing.com/cr?IG=1863FE449C574076B08CCC13306BF39B\&CID=01B 75E3138EF69E407BC54DC39E9682F\&rd=1\&h=uU7EpzwuR74Ra4FKxiy4PWwU xIhEW9wWGucZzVo117o\&v=1\&r=http\%3a\%2f\%2fwww.iiste.org\%2fJournals\%2f index.php\%2fEJBM\%2farticle\%2fviewFile\%2f30573\%2f31412\&p=DevEx,5061.1

Sameer, Y., \& Ohly, S. (2017). Innovative Behavior of Employees: A model of Antecedents and Consequences, A Deeper Look at Psychological and Organizational Factors. CYRUS Institute of Knowledge, 61.

Scott, S. G., \& Bruce, R. A. (1994). Determinants of innovative behavior: a path model of individual innovation in the workplace. Academy of Management Journal, 37(3), 580607. doi: $10.2307 / 256701$

Seibert, S. E., Wang, G., \& Courtright, S. H. (2011). Antecedents and consequencesof psychological and team empowerment: A meta-analytic review. Journal ofApplied Psychology, 96, 981-1003.

Shamir, B., R. J. House and M. B. Arthur (1993). 'The motivational effects of charismatic leadership: a self-concept basedtheory', Organizational Science, 4, pp. 577-594.

Sharifirad, M. S. (2013). Transformational leadership, innovative work behavior, and employee well-being. Global Business Perspectives, 1(3), 198-225.

Shin, S. J., \& Zhou, J. (2003). Transformational leadership, conservation, and creativity: Evidence from Korea. Academy of Management Journal, 46(6), 703-714. http://dx.doi.org/10.2307/30040662.

Siegall, M., \& Gardner, S. (2000). Contextual factors of psychological empowerment. Personnel Review, 29(6), 703-722. doi:10.1108/00483480010296474

Sluss, D. M., \& Ashforth, B. E. (2007). Relational identity and identification: Defining ourselves through work relationships. Academy of Management Review, 32, 9-32.

Spreitzer, G. M. (1995). An empirical test of a comprehensive model of intrapersonal empowerment in the workplace. American Journal of Community Psychology, 23(5), 601-629. doi: 10.1007/BF02506984

Spreitzer, G. M. (1995). Individual empowerment in the workplace: Di-mensions, measurement, validation. Academy of Management Jour-nal, 38, 1442-1465. 
Spreitzer, G. M. (1995b). Psychological, Empowerment In The Workplace: Dimensions, Measurement And Validation. Academy of Management Journal,38(5), 1442-1465. doi:10.2307/256865

Spreitzer, G. M. (2008). Taking stock: A review of more than twenty years of research on empowerment at work. Handbook of organizational behavior, 54-72.

Staehle-Moody CM (1998). Adaptation to organizational change: A study of middle managers' coping styles and their correlates. Dissertation Abstracts International: Section B: Sci. Engineer. 59(5- B):2471.

Tahsildari, H., Hashim, M. T., \& Wan, W. N. (2014). The influence of transformational leadership on organizational effectiveness through employees' innovative behaviour. Journal of Economics and Sustainable Development, 5(24), 225-35.homas

K.W. \& Velthouse B.A. (1990). Cognitive elements ofempowerment: an 'interpretive' model of intrinsic taskmotivation. Academy of Management Review, 15, 666-681.

Thomas, K. W., \& Velthouse, B. A. (1990). Cognitive elements of empowerment: An "interpretive" model of intrinsic task motivation. Academy of management review, 15(4), 666-681.

Torokoff, M. (2015). Analysis of Directing the Innovation Process and its Relation to Middle Level Manager's Work: the Case of Estonian Enterprises. Engineering Economics, 21(4).

Uçar, D., \& Ötken, A. B. (2013). Perceived organizational support and organizational commitment: The mediating role of organization based self-esteem. Dokuz Eylül Üniversitesi İktisadi ve İdari Bilimler Fakültesi Dergisi, 25(2).

Van Dyne, L., Vandewalle, D., Kostova, T., Latham, M. E., \& Cummings, L. L. (2000). Collectivism, propensity to trust and self-esteem as predictors of organizational citizenship in a non-work setting. Journal of organizational behavior, 3-23.

Walumbwa, F. O., \& Hartnell, C. A. (2011). Understanding transformational leadershipemployee performance links: The role of relational identification and selfefficacy. Journal of Occupational and Organizational Psychology,84(1), 153-172. doi:10.1348/096317910x485818.

Wang, X. H. F., \& Howell, J. M. (2012). A multilevel study of transformational leadership, identification, and follower outcomes. The Leadership Quarterly, 23(5), 775-790.

Yukl, G. (2010). Leadership in organizations (7th ed.). Upper Saddle River, NJ: Prentice Hall.

Zhou, Q., \& Pan, W. (2015). A Cross-Level Examination of the Process Linking Transformational Leadership and Creativity: The Role of Psychological Safety Climate. Human Performance,28(5), 405-424. doi:10.1080/08959285.2015.1021050 